\title{
Advance "Alarming" of Cancer in the World and in our Country (Argentina)
}

\author{
Adrian Pablo Hunis* \\ Recertified Specialist in Oncology, Maimonides University, Argentina
}

Submission: January 24, 2020; Published: February 18, 2020

"Correspondence Author: Adrian Pablo Hunis, Associate Professor of Internal Medicine (UBA), Director of the Medical Specialist in Oncology (UBA), Professor of Oncology (Maimonides University), Argentina

\section{Introduction}

One in five Argentines will have throughout their life, some type of cancer. The World Health Organization (WHO) warns that 10 million people will die in the world this year from the disease.

\section{Why are there more and more cases?}

In Argentina, as in the whole world, cancer advances. Some increase their incidence, others go down. Among the most common causes are the highest life expectancy, The Main Risk Factor is Age, and certain modern habits. On this issue, women and men go hand in hand. The positive: diagnoses and treatments improve, but it must be controlled. 20 percent of men and women will develop some type of cancer during their life in Argentina, while one in eight men and one in eleven women will die from this disease in the world, according to the Globocan 2018 report presented on 12 September by the International Cancer Research Center (IARC), which depends on the World Health Organization (WHO) [1,2].

The same report ensures that this year there will be 18 million new cases in the world, and that almost ten million people will die. Lung cancer is the most aggressive, with 1.8 million deaths expected this year in the world (18.4\% of the total), ahead of colorectal cancer $(881,000$ deaths, $9.2 \%$ of the total), of stomach $(783,000)$ and liver $(782,000)$ [3-5]. "These new figures show that much remains to be done to respond to the alarming increase in the global burden of cancer and that prevention must play a key role,"Christopher Wild, director of IARC, said in a statement. It is urgent to implement effective prevention and early detection policies to complete the treatments. "

Almost half of the new cases and more than half of the world's cancer deaths in 2018 will be in Asia, mainly in China, partly because this region accounts for almost $60 \%$ of the world's population. Among men, the lung is the most diagnosed and is the leading cause of death from cancer, with about one in five cases.
The IARC speaks of a "worrying increase" of this cancer among women: for them it is the leading cause of death from tumors in 28 countries.

Breast cancer is still the one that causes the most deaths: 627,000 a year and represents about a quarter of the new cases diagnosed. The second is the colorectal in developed countries and the cervix in developing countries. The increase in cancer is due to population growth, population aging and the evolution of the frequency of risk factors such as smoking, obesity, lack of exercise and unbalanced diet, the report said. Between "one third and two fifths" of the new cases could be avoided by eliminating or reducing the exposure of known risk factors related to the way of life and the environment. The Argentine Republic does not differ too much from the world average. It has an incidence rate of 217 cases per 100,000 inhabitants, a figure that positions it within countries with a medium-high incidence of cancer.

The Globocan 2018 already speaks of an incidence of 230 thousand cases. Breast cancer remains the largest number of new cases. Colorectal also increases in both sexes, and among men the most prevalent are still prostate and lung. Breast and colorectal cancer are more common in developed countries. And in this Argentina has more similar figures to Europe than the rest of Latin America and Asia, is it because Argentina has a lot of middle class? These cancers are related to new habits of more sedentary lifestyle and eating. While there is no anti-cancer diet, we know that obesity is a risk factor. We know the same thing about cigarettes, directly related to lung cancer, but harmful to all the other organs and tissues of our body.

Absolute numbers grow, but at the rate of the population. What is on the rise in women is lung and colorectal cancer, and it has to do with habits. Women have not quit smoking, tend to sedentary, do not consume as many vegetables and fruits (Figure 1). 


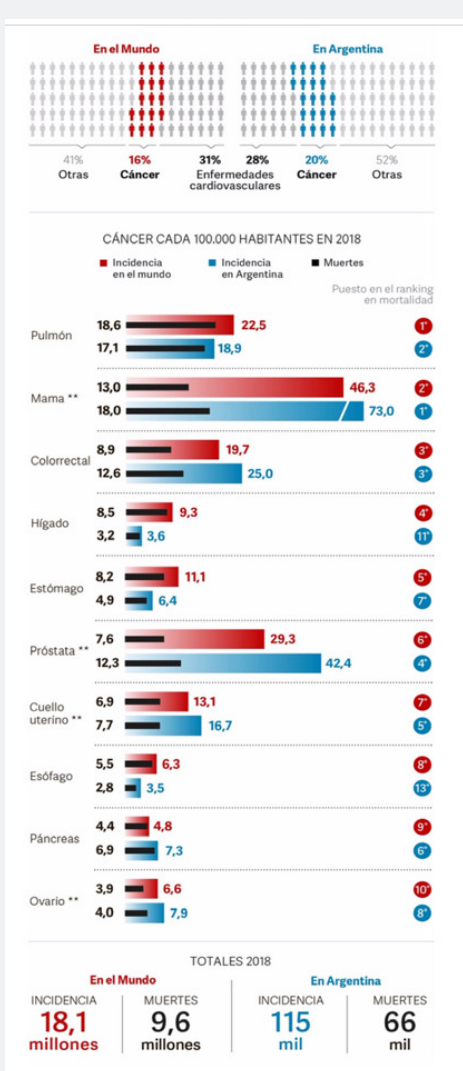

Figure 1: The Cancer in the Argentina.

In any case, breast cancer is still the one with the highest incidence, as in the first world, and is related to obesity, smoking, the smallest number of children and breastfeeding periods. The growth of these three types of cancer are also related to their greater diagnosis because there is now screening, which detects the disease earlier.

\section{Conclusions, simple, obvious, but effective!}

Quit smoking, do not abuse alcohol, eat lots of fruits and vegetables, do physical activity and undergo controls, especially women undergoing breast exams and women and men after age 45 do not run away from colonoscopies. In cancer, genetic and hereditary issues are very important. There are already genetic tests that can help with early diagnoses.

\section{References}

1. Globocan 2018.

2. IARC

3. CLARÍN

4. https://www.iarc.fr/en/office-dir/director/dirbiography.php

5. Adrián Pablo Huñis (2016) A current view of oncology in Argentina Current vision of cancer in Argentina. ecancer medical science 10: 622. 
This work is licensed under Creative Commons Attribution 4.0 License DOI: 10.19080/CTOIJ.2020.15.555919

\section{Your next submission with Juniper Publishers will reach you the below assets}

- Quality Editorial service

- Swift Peer Review

- Reprints availability

- E-prints Service

- Manuscript Podcast for convenient understanding

- Global attainment for your research

- Manuscript accessibility in different formats ( Pdf, E-pub, Full Text, Audio)

- Unceasing customer service

Track the below URL for one-step submission https://juniperpublishers.com/online-submission.php 